\title{
Elongation factor NusG interacts with termination factor $\rho$ to regulate termination and antitermination of transcription
}

\author{
Joyce Li, ${ }^{1}$ Stephen W. Mason, ${ }^{1,2}$ and Jack Greenblatt ${ }^{1,2,3}$ \\ ${ }^{1}$ Banting and Best Department of Medical Research and ${ }^{2}$ Department of Molecular and Medical Genetics, University \\ of Toronto, Toronto, Ontario M5G 1L6 Canada
}

\begin{abstract}
NusG is a transcriptional elongation factor in Escherichia coli that aids transcriptional antitermination by the phage $\lambda \mathrm{N}$ protein. By using NusG affinity chromatography, we found that NusG binds directly and selectively to termination factor $\rho$. NusG was shown previously to be needed for termination by $\rho$ in vivo, and we show here that NusG increases the efficiency of termination by $\rho$ at promoter-proximal sites in vitro. The rho026 mutation makes termination by $\rho$ less dependent on NusG. It also makes antitermination by $N$ at $\rho$-dependent terminators and the binding of $\rho$ to NusG temperature sensitive. Therefore, the interaction of NusG with $\rho$ is important both for $\rho$-dependent termination and for antitermination by $N$ at $\rho$-dependent terminators.
\end{abstract}

[Key Words: Termination; $\rho$-factor; antitermination; $\mathrm{N}$ protein; NusG]

Received June 18, 1992; revised version accepted October 30, 1992.

The early operons of phage $\lambda$ have multiple transcriptional terminators, some of which are absolutely dependent on the Escherichia coli termination factor $\rho$ (Roberts 1969). $\rho$ Factor binds RNA upstream of the termination sites (Sharp and Platt 1984; Lau and Roberts 1985; Chen et al. 1986; Faus and Richardson 1990), translocates along the nascent RNA (Galluppi and Richardson 1980), and uses an ATP-dependent RNA-DNA helicase activity (Brennan et al. 1987) to release the nascent RNA when RNA polymerase pauses at a $\rho$-dependent terminator (Rosenberg et al. 1978; Richardson and Conaway 1980; Shigesada and Wu 1980; Lau et al. 1983; Morgan et al. 1983, 1984). Termination at the early terminators of $\lambda$ is prevented by the phage $\mathrm{N}$ protein (Roberts 1969; Luzzati 1970; Lozeron et al. 1977). Each $\lambda$ early operon is a target for $\mathrm{N}$ action because $\mathrm{N}$ recognizes the RNA form (Horwitz et al. 1987; Nodwell and Greenblatt 1991) of an $\mathrm{N}$ utilization site (nut site) that is located between the promoter and first terminator of the operon (Friedman et al. 1973; Rosenberg et al. 1978; Salstrom and Szybalski 1978; de Crombrugghe et al. 1979).

Antitermination by $\mathrm{N}$ involves the $E$. coli proteins NusA, NusB, NusG, and ribosomal protein S10 (Friedman and Baron 1974; Keppel et al. 1974; Friedman et al. 1976, 1981; Das and Wolska 1984; Goda and Greenblatt 1985; Li et al. 1992; Sullivan et al. 1992). N-modified

\footnotetext{
${ }^{3}$ Corresponding author.
}

RNA polymerase carries $\mathrm{N}$ protein and all of the host elongation factors in stable association with the nut site RNA as it transcribes DNA distal to the nut site (Barik et al. 1987; Horwitz et al. 1987; Mason and Greenblatt 1991; Nodwell and Greenblatt 1991; Li et al. 1992). Assembly of a stable $\mathrm{N}$-modified transcription complex is highly cooperative (Mason and Greenblatt 1991; Nodwell and Greenblatt 1991), and the stability of the complex is maintained by multiple protein-protein (Greenblatt and Li 1981 a,b; Mason and Greenblatt 1991; Mason et al. 1991; Li et al. 1992) and protein-RNA (Nodwell and Greenblatt 1991) interactions. NusA, S10, and NusG all bind to $E$. coli RNA polymerase (Greenblatt and Li 1981b; Mason and Greenblatt 1991; Li et al. 1992). In the case of NusG, its binding to RNA polymerase is weak and its stable association with $\lambda$ transcription complexes depends on the presence of $\mathrm{N}$ and a nut site (Mason and Greenblatt 1991; Li et al. 1992). Although the host factor NusA suffices in vitro for antitermination by $\mathrm{N}$ at a simple terminator (Whalen et al. 1988) or a $\rho$-dependent terminator (Mason et al. 1992) located just downstream from a nut site, NusB, S10, and NusG increase the stability of the $\mathrm{N}$-modified transcription complex (Mason and Greenblatt 1991; Nodwell and Greenblatt 1991) and enable N-modified RNA polymerase to transcribe more processively through the multiple termination sites of the $\lambda$ early operons (Mason et al. 1992).

NusG was identified and purified on the basis of its requirement for effective antitermination by $\mathrm{N}$ in vitro 
(Li et al. 1992). The effects of the nusG4 mutation on antitermination by $\mathrm{N}$ suggest that NusG is also involved in antitermination by $\mathbf{N}$ in vivo (Sullivan et al. 1992), although there may be an alternative pathway for antitermination by $\mathrm{N}$ that does not involve NusG (Sullivan and Gottesman 1992). NusG was also shown recently to be required for termination by $\rho$-factor in vivo (Sullivan and Gottesman 1992). To obtain more information about the roles of NusG in transcription, we have now performed affinity chromatography experiments with immobilized NusG. Our results indicate that NusG interacts directly with termination factor $\rho$ and not only contributes directly to antitermination by $\mathrm{N}$ but also to the efficiency of termination by $\rho$-factor.

\section{Results}

\section{NusG binds directly to termination factor $\rho$}

NusG was purified to near homogeneity from an overproducer strain (Fig. 1A) and attached covalently to Affigel 10 (Formosa et al. 1991). Crude extract from E. coli cells was loaded onto microaffinity columns (Greenblatt and Li 1981a) containing varying concentrations of immobilized NusG. After each column was washed with loading buffer, the columns were eluted with buffer containing $1 \mathrm{M} \mathrm{NaCl}$, and the eluates were analyzed by SDSPAGE followed by staining with silver (Morrissey 1981) (Fig. 1B). An E. coli protein whose apparent molecular mass was $50 \mathrm{kD}$ bound reproducibly to NusG columns in a concentration-dependent manner (lanes 2-6) and not to a control column containing no immobilized protein (lane 1). The 50-kD NusG-binding protein was the same size as termination factor $\rho$ (Roberts 1969), and Western blotting with anti- $\rho$ serum established that it was $\rho$-factor (Figs. 1C and 8). The binding of $\rho$-factor to NusG was extremely selective: Although many E. coli proteins bound nonspecifically to the agarose of our column matrices and were eluted with salt (Fig. 1B, lane 1), no other E. coli protein besides $\rho$-factor bound exclusively to columns containing immobilized NusG. Also, no additional NusG-binding proteins were detected when the columns were eluted with buffer containing SDS /data not shown). By collecting a series of fractions during the washing of a $1-\mathrm{mg} / \mathrm{ml}$ (i.e., $5 \times 10^{-5} \mathrm{M}$ ) NusG column and analyzing them by Western blotting with anti- $\rho$ serum (data not shown), we found that all of the $\rho$-factor in the extract was retarded by the immobilized NusG and moved at approximately one-third the rate of the loading and wash buffers. If we assume that all of the immobilized NusG was able to bind $\rho$-factor, the dissociation constant of the interaction would be $\sim 3 \times 10^{-5} \mathrm{M}$.

We then tested whether NusG binds directly to $\rho$ by chromatographing purified $\rho$-factor on NusG and control columns in the same conditions (Fig. ID). Although a small amount of $\rho$-factor bound to the agarose of a control column (lane 1), much more $\rho$-factor bound to NusG columns (lanes 2,3). Therefore, NusG can bind $\rho$ directly in the absence of any other $E$. coli protein. Because $\rho$-factor is a hexameric protein (Roberts 1969; Oda and Takanami 1972; Finger and Richardson 1982), we wished to establish that $\rho$-factor was not simply binding to a $\rho$-factor contaminant in our NusG preparation. By subjecting purified NusG to Western blotting with anti- $\rho$ serum, we determined that a $1-\mathrm{mg} / \mathrm{ml}$ NusG microcolumn contained $<1-2$ ng of immobilized $\rho$-factor (data not shown). Because such a column, which contained 10-20 $\mu \mathrm{g}$ of immobilized NusG, could bind $\geqslant 1 \mu \mathrm{g}$ of $\rho$-factor /data not shown), $\rho$-factor could not simply have been binding to a $\rho$-factor contaminant in our NusG preparation. In the experiment shown in Figure 1B, some E. coli RNA polymerase (subunits $\beta, \beta^{\prime}$, and $\alpha$ ) bound to the agarose column matrix (lane 1), and binding of RNA polymerase

Figure 1. Binding of $\rho$-factor to NusG affinity columns. (A) Purified wild-type NusG used for affinity chromatography was analyzed by SDS-PAGE on a $12.5 \%$ gel followed by staining with Coomassie brilliant blue. $(B, C)$ NusG affinity chromatography. S30 extract from E. coli $(50 \mu \mathrm{l}, 1$ mg protein) was loaded at $23^{\circ} \mathrm{C}$ onto $30-\mu l$ microcolumns containing the indicated concentrations of immobilized NusG4. The columns were washed with $300 \mu$ l of affinity chromatography buffer (ACB) and eluted with $50 \mu \mathrm{l}$ of ACB containing $1 \mathrm{M}$ $\mathrm{NaCl}$. Eluted proteins $(25 \mu \mathrm{l})$ were analyzed by SDS-PAGE on a $13.5 \%$ gel followed by staining with silver (Morrisey 1981) $(B)$ or transferred to nitrocellulose and Western blotted with antisera against NusA, NusB, and $\rho(C)$. Three antisera were used in this Western blot, but only

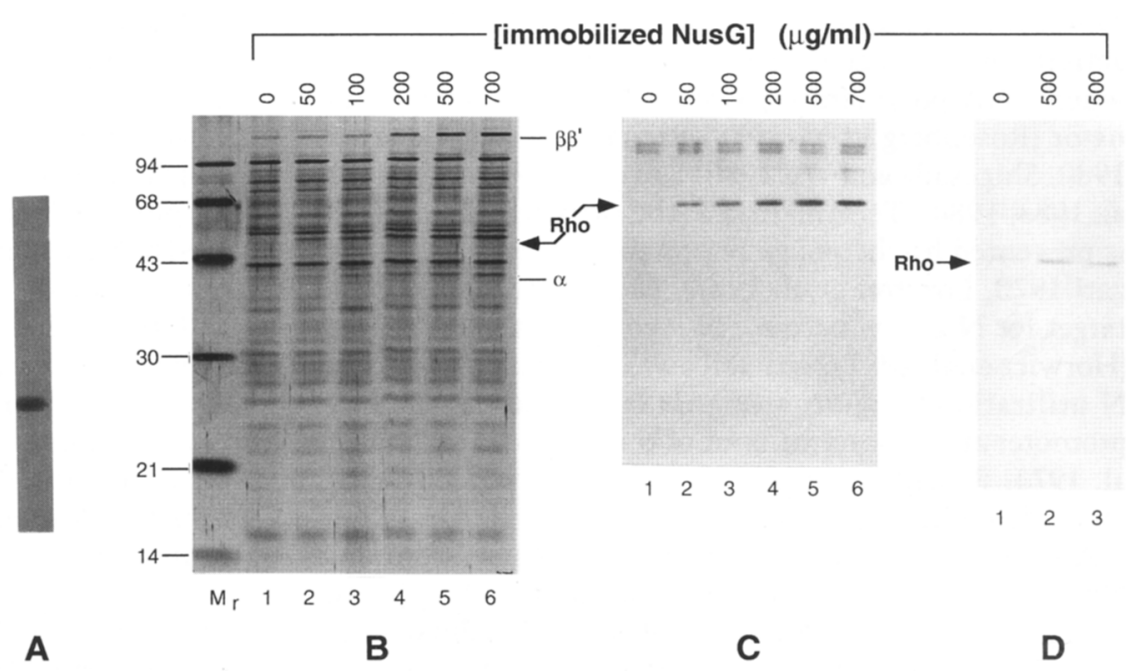
anti- $\rho$ is necessary to detect the NusG-binding protein (see Fig. 7). (D) Purified $\rho(1 \mu \mathrm{g})$ in $20 \mu \mathrm{l}$ of ACB containing $2 \%$ skim milk and $100 \mu \mathrm{g} / \mathrm{ml}$ of BSA was chromatographed at $23^{\circ} \mathrm{C}$ on $20-\mu \mathrm{l}$ columns containing $500 \mu \mathrm{g} / \mathrm{ml}$ of immobilized wild-type NusG (lane 2), NusG4 (lane 3), or no immobilized protein (lane 1). The $1 \mathrm{M} \mathrm{NaCl}$ eluates were analyzed by Western blotting with anti-p. (M) Molecular weight standards. 
was increased by the presence of immobilized NusG (lanes 4-6). However, we have not been able to detect reproducibly the binding of RNA polymerase to immobilized NusG. In other experiments we found that purified RNA polymerase and the other $E$. coli cofactors for $\mathrm{N}$-mediated antitermination, NusA, NusB, and ribosomal protein S10, did not bind directly to a NusG column or affect the binding of $\rho$ to NusG (data not shown).

Many mutations in genes encoding $E$. coli host factors prevent antitermination by $\mathrm{N}$. In particular, the nusA1 and nusE71 mutations prevent antitermination by $\mathrm{N}$ (Friedman and Baron 1974; Friedman et al. 1981), probably because the mutant proteins do not help N, NusB, and NusG to associate with RNA polymerase transcribing the $\lambda p R$ operon (Horwitz et al. 1987; Horwitz 1988; Mason and Greenblatt 1991). The nusG4 mutation has no known effect on termination by $\rho$-factor, but it partially reverses the effects of the nusA 1 and nusE71 mutations on antitermination by $\mathrm{N}$ in vivo (Sullivan et al. 1992). Therefore, the nusG4 mutation likely facilitates the binding of N, NusB, and NusG to a $\lambda$ transcription complex containing a mutant NusA or S10 protein. As shown in Figure 1D, the same amount of $\rho$ bound to a column containing wild-type NusG (lane 2) as to a column in which the immobilized NusG was derived from a strain with the nusG4 mutation (lane 3). Thus, we could not detect an effect of the nusG4 mutation on the binding of NusG to $\rho$; therefore, this mutation may be unrelated to the association of NusG with $\rho$.

\section{A role for NusG in termination by $\rho$-factor}

Sullivan and Gottesman (1992) recently showed that NusG was essential for termination by $\rho$ in vivo. Thus, our finding that NusG could interact directly with $\rho$-factor suggested that NusG might have a direct role in termination by $\rho$. Roberts (1969) showed that $\rho$ could terminate transcription in vitro by $E$. coli RNA polymerase at a $\rho$-dependent terminator in the absence of any other factor. In these experiments $\rho$ worked well only at low ionic strength and functioned poorly even at the moderate ionic strengths presumably characteristic of the intracellular milieu (Goldberg 1970; Richardson 1970). Therefore, we tested whether NusG could improve termination by $\rho$ in conditions in which $\rho$ could not function well on its own.

The simplest assay for termination by $\rho$ is its ability to inhibit the total transcription of DNAs on which $\rho$-dependent terminators lie downstream of strong promoters (Roberts 1969). When we used a plasmid in which the strong $\lambda$ promoter $p R$ is followed by the cro gene and the $\lambda \rho$-dependent terminator $t R 1, \rho$ inhibited transcription $\sim 65 \%$ in reactions containing $100 \mathrm{mM} \mathrm{KCl}$ and $5 \mathrm{mM} \mathrm{Mg}$ acetate, as shown in Figure 2A. In these conditions NusG had only a small effect on the ability of $\rho$ to inhibit transcription. On the other hand, in reactions containing $200 \mathrm{~mm} \mathrm{KCl}$ and $10-20 \mathrm{~mm} \mathrm{Mg}$ acetate, $\rho$ inhibited transcription only slightly on its own $(\sim 25-35 \%)$, and its effect was substantially enhanced by NusG (Fig. 2A,B). Therefore, our results suggested that NusG could improve termination substantially by $\rho$ at $t R 1$. The effect of NusG was half-maximal at 25-50 nM (Figs. 2A and 3B), about two to four times greater than the concentration of NusG required for a half-maximal effect on anti-termination by $\mathrm{N}$ ( $\mathrm{Li}$ et al. 1992).

The $\lambda p R-c r o-t R 1$ cassette is only one of the transcription units present on the plasmid used in the total transcription experiments shown in Figure 2. To confirm
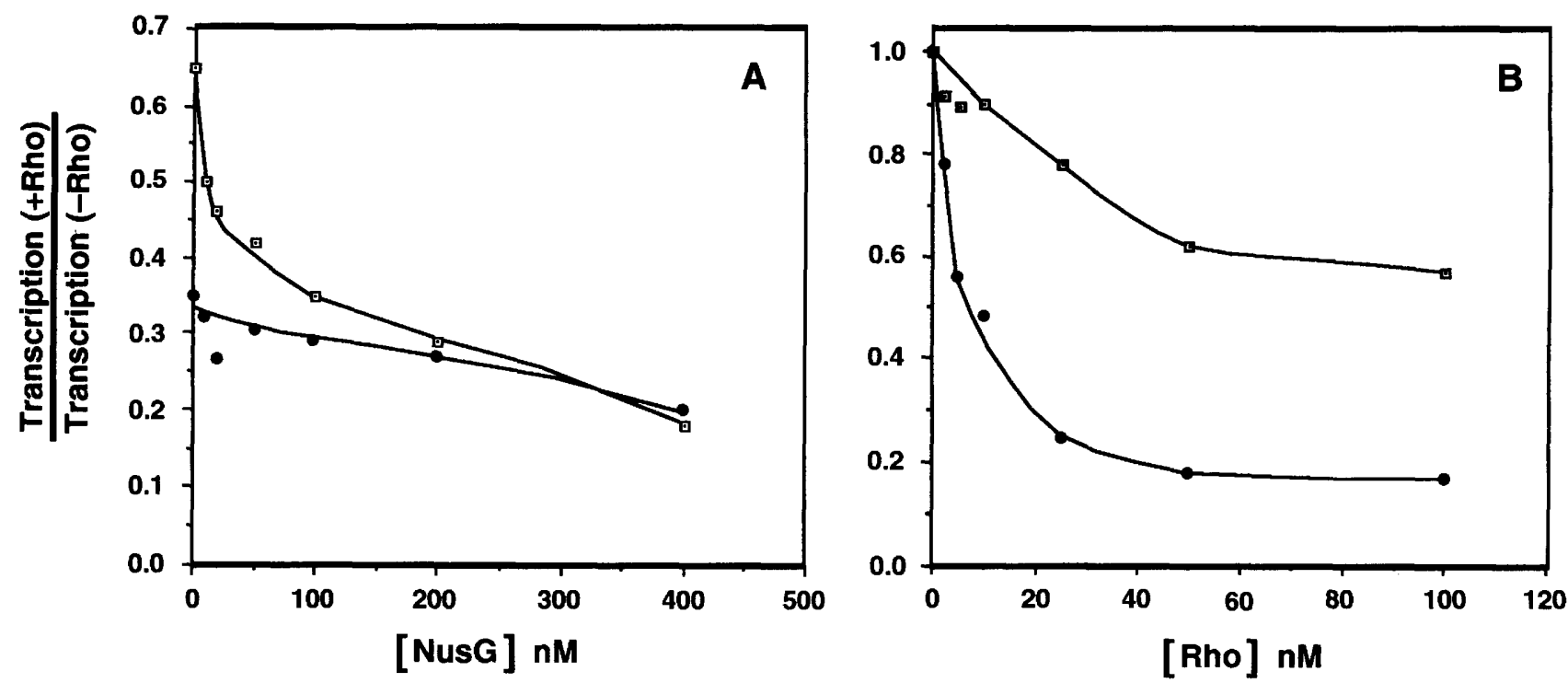

Figure 2. Effect of NusG on $\rho$ activity. (A) Reactions without or with $50 \mathrm{~nm} \rho$-factor contained plasmid pLS1 DNA (Lau and Roberts 1985), the indicated concentrations of NusG, $10 \mathrm{~mm}$ Tris- $\mathrm{HCl}$ (pH 7.9), and either $100 \mathrm{mM} \mathrm{KCl,} 5 \mathrm{~mm} \mathrm{Mg}$ acetate (O) or $200 \mathrm{mM} \mathrm{KCl}$, $10 \mathrm{~mm} \mathrm{Mg}$ acetate $(\square) .(B)$ Reactions without $(\square)$ or with $(0) 500 \mathrm{nM}$ NusG contained pLS1 DNA, the indicated concentrations of $\rho$ hexamers, and buffer containing $10 \mathrm{~mm}$ Tris- $\mathrm{HCl}(\mathrm{pH} 7.9), 200 \mathrm{mM} \mathrm{KCl}$, and $10 \mathrm{mM} \mathrm{Mg}$ acetate. Total transcription was measured and related to reactions lacking $\rho$-factor. 
Li et al.

A

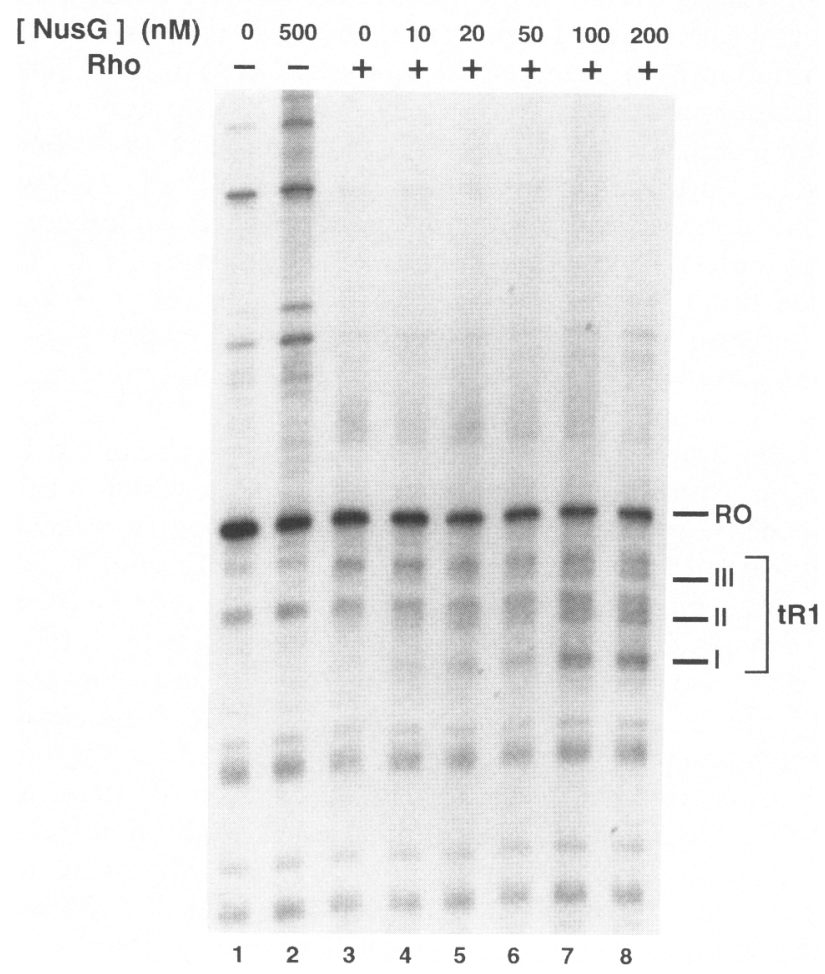

B

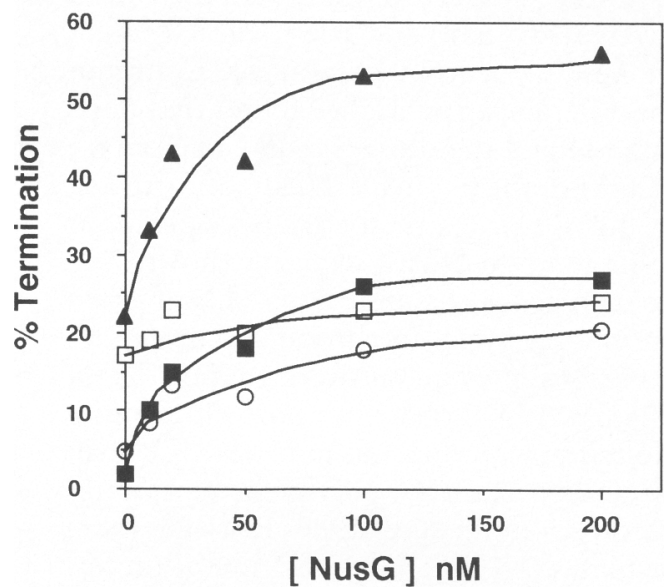

Figure 3. Effect of NusG on $\rho$-dependent termination at $t R 1$. $(A)$ Runoff transcription assays in buffer containing $10 \mathrm{mM}$ Tris- $\mathrm{HCl}$ ( $\mathrm{pH} 7.9$ ), $200 \mathrm{~mm} \mathrm{KCl}$, and $10 \mathrm{~mm} \mathrm{Mg}$ acetate contained $30 \mathrm{nM}$ of a HinfI DNA fragment with the $p R-c r o-t R 1$ region of $\mathrm{pLSI}$ (Lau and Roberts 1985), the indicated concentrations of NusG, and, where indicated, $50 \mathrm{nM} \rho$-factor. The ${ }^{32} \mathrm{P}$-labeled reaction products were analyzed on a $4 \%$ polyacrylamide gel containing $8 \mathrm{M}$ urea. The positions of termination sites I, II, and III of $t R 1$ (Lau et al. 1983) were deduced by comparison with a set of runoff transcripts on the same DNA fragment cleaved with various restriction enzymes (not shown). The smaller RNAs visible near the bottom of the gel involve pausing by RNA polymerase that is independent of NusG and $\rho$-factor. $(B)$ Quantitation of the experiment shown in $A$ based on densitometric scans of films at different exposure times. $\rho$-Independent background bands visible in lane 1 of $A$ were subtracted from all values. (A) Total; ( $\square)$ site III; (O) site II; ( $)$ site I.

that NusG could act as a cofactor for termination by $\rho$ specifically at $t R 1$, runoff transcription assays in buffer containing $200 \mathrm{~mm} \mathrm{KCl}$ and $10 \mathrm{mM} \mathrm{Mg}$ acetate were performed on a small DNA fragment containing $p R$, cro, and $t R 1$ (Fig. 3). In the absence of $\rho$-factor, NusG had no effect on its own (Fig. 3A, lanes 1,2). $\rho$ was very inefficient at terminating transcription on its own (Fig. 3A, lane 3): although termination at site III of $t R 1$ was reasonable (see Lau et al. 1983), there was little $\rho$-dependent termination at sites I and II of $t R 1$. The addition of increasing amounts of NusG to the reaction led to increasingly more efficient termination, especially at the more promoter-proximal sites I and II of $t R 1$ (Fig. 3A, lanes 4-8). Quantitation of this experiment is shown in Figure 3B. In these reactions containing $200 \mathrm{mM} \mathrm{KCl}$, NusG increased the overall termination efficiency of $\rho$ at $t R 1$ from $22 \%$ to $56 \%$.

The $\lambda p R$ early transcription unit is many kilobase pairs long and contains several terminators. Roberts (1969) showed that transcription of the downstream region of the $p R$ operon is very sensitive to $\rho$-factor in vitro in reactions containing $100 \mathrm{~mm} \mathrm{KCl}$. To examine the effect of NusG on the transcription of the $p R$ operon in intact $\lambda$ DNA (Fig. 4A), ${ }^{32}$ P-labeled RNA produced in such reactions was hybridized to various fragments of DNA derived from the $\lambda p R$ operon. In reactions containing $200 \mathrm{~mm} \mathrm{KCl}$ and $10 \mathrm{~mm} \mathrm{Mg}$ acetate (Fig. 4B), $\rho$ had little or no effect, in the presence or absence of NusG, on the synthesis of $\lambda$ RNA hybridizing to DNA fragment 1 located upstream of $t R 1$, the first terminator in the operon. However, NusG strikingly improved the ability of $\rho$ to inhibit synthesis of RNA hybridizing to $p R$ operon DNA fragments 2,3 , and 4 located downstream of $t R 1$ (cf. lines a and $c$ ). This inhibition by $\rho$ reflected increased $\rho$-dependent termination of transcription, rather than reduced initiation downstream of $t R 1$, because synthesis of RNA hybridizing to $p R$ operon fragments $1-4$ was sensitive to $\lambda$ repressor, which specifically inhibits transcription from $p R$ and $p L$ (Fig. $4 \mathrm{~B}$, line e). Thus, as shown in Figure 4C, NusG substantially improved the activity of $\rho$ on the $\lambda p R$ operon when $E$. coli RNA polymerase transcribed intact $\lambda$ DNA.

Most RNA polymerase molecules that synthesized RNA hybridizing to the more distal $p R$ operon fragments 5,6 , and 7 likely initiated at $p R^{\prime}$ rather than $p R$, because transcription of this region was only slightly sensitive to $\lambda$ repressor (Fig. 4B, cf. lines $d$ and e). $\rho$-factor had little effect on transcription of this region in the presence or absence of NusG (cf. line a with b and line c with d), probably because $t R^{\prime}$, which lies just downstream of $p R^{\prime}$, is a $\rho$-independent terminator. However, NusG, by itself, slightly reduced synthesis of RNA hybridizing to fragments 5, 6, and 7 (cf. line a with $\mathrm{c}$ and line $\mathrm{b}$ with $\mathrm{d}$; see also Fig. 4 C). Thus, although NusG had little effect on 


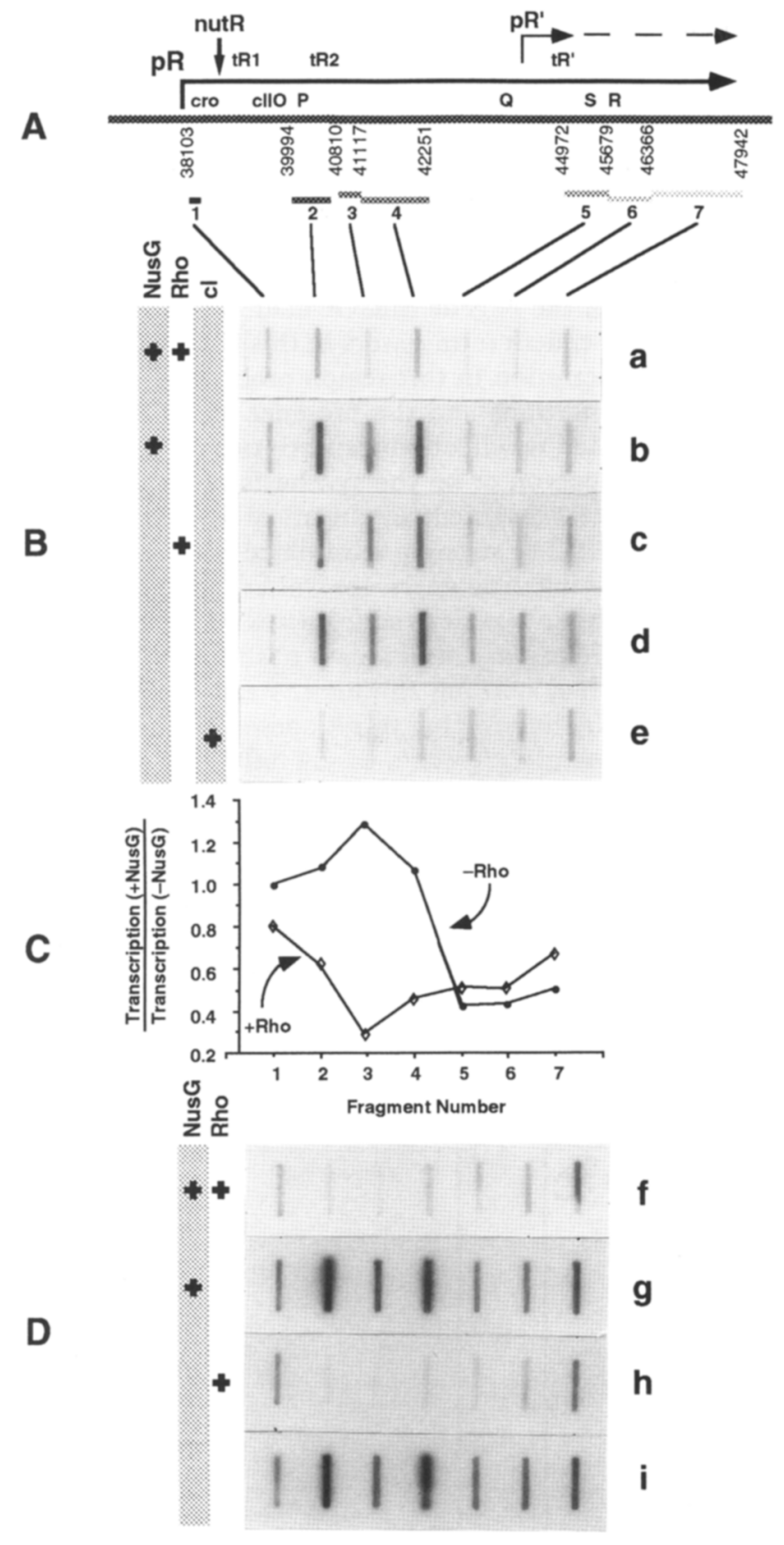

the efficiency of the $\rho$-independent terminator $t R 2$, it may slightly improve the efficiency of the $\rho$-independent terminator $t R^{\prime}$.

Zou and Richardson (1991) have shown that the activity of $\rho$-factor in vitro is substantially enhanced when the $\mathrm{KCl}$ in the reaction is replaced by potassium glutamate. As shown in Figure 4D (lines $\mathrm{f}-\mathrm{i}$ ), in reactions containing potassium glutamate $\rho$-factor suppressed transcripton of the downstream regions of the $p R$ operon almost completely on its own (line h), and NusG had no effect (cf. line $f$ with $h$ ). Thus, the NusG requirement for termination by $\rho$ depends on the ionic conditions of the reaction. The use of potassium glutamate instead of $\mathrm{KCl}$
Figure 4. Effects of $\rho$ and NusG on transcription of the $\lambda p R$ operon. $\lambda$ cI857 S7 DNA was transcribed at $37^{\circ} \mathrm{C}$ with or without $250 \mathrm{nM}$ NusG, $33 \mathrm{nM} \rho$, and $380 \mathrm{nM} \lambda \mathrm{cI}$ repressor, as indicated. The reaction buffers contained $10 \mathrm{~mm}$ Tris acetate $(\mathrm{pH} 7.9)$, and either $200 \mathrm{~mm} \mathrm{KCl}, 10 \mathrm{mM} \mathrm{Mg}$ acetate $(B)$ or $150 \mathrm{~mm}$ potassium glutamate, $4 \mathrm{mM} \mathrm{Mg}$ acetate $(D)$. The indicated fragments of $\lambda$ DNA $(A)$ were covalently bound to nylon membranes, and ${ }^{32} \mathrm{P}$ labeled RNA made in the reactions was hybridized to the DNA on the membranes. Autoradiographs of the membranes are shown. Densitometric scans were quantitated for $B$ reactions $a-d$, and the data were expressed in $C$ to indicate the effect of NusG on transcription of each fragment in the presence $|\diamond|$ or absence ( $)$ of $\rho$-factor. There was no detectable hybridization to a control plasmid containing no $\lambda$ DNA insert (data not shown).

probably makes termination by $\rho$ independent of NusG at certain terminators. The presence of other salts, in addition to potassium glutamate, in the complex ionic environment of the cell, nevertheless may make $\rho$-factor activity in vivo dependent on NusG (Sullivan and Gottesman 1992).

A role for the $\rho-N u s G$ interaction in transcriptional antitermination

The above experiments established that the $\rho-$ NusG interaction has an important role in termination by $\rho$-factor. To investigate the relevance of the $\rho-\mathrm{NusG}$ interac- 
Li et al.

tion for antitermination by the $\lambda \mathrm{N}$ protein, we took advantage of the rho026 mutation, which prevents antitermination by $\mathrm{N}$ at $\rho$-dependent terminators in vivo at high temperatures but not at low temperatures (Simon et al. 1979; Das et al. 1983).

To determine whether the rho026 mutation had a direct effect on antitermination by $\mathrm{N}$ we performed the experiments shown in Figures 5 and 6 . First, we took advantage of the fact that $\mathrm{N}$ can stimulate the net transcription of DNA templates containing $\lambda$ early operons in reactions containing NusA, NusB, S10, NusG, and $\rho$-factor ( $\mathrm{Li}$ et al. 1992). Because the rho026 mutation is temperature sensitive, we carried out transcription at $30^{\circ} \mathrm{C}, 37^{\circ} \mathrm{C}$, or $42^{\circ} \mathrm{C}$ in reactions containing either wildtype $\rho$-factor or $\rho$-factor purified from a strain with the rho026 mutation. As shown in Figure 5a, $\mathrm{N}$ stimulated transcription of $\lambda$ DNA at $30^{\circ} \mathrm{C}$ in reactions containing either wild-type $\rho$-factor or the Rho026 mutant protein. $\mathrm{N}$ stimulated transcription less well at $37^{\circ} \mathrm{C}$ or $42^{\circ} \mathrm{C}$ than at $30^{\circ} \mathrm{C}$ in reactions containing wild-type $\rho$ (Fig. $5 \mathrm{a}-\mathrm{c}$ ), indicating that antitermination by $\mathrm{N}$ is intrinsically somewhat temperature sensitive. However, $\mathrm{N}$ did not stimulate transcription of $\lambda$ DNA at all at $37^{\circ} \mathrm{C}$ or $42^{\circ} \mathrm{C}$ if the reaction contained mutant $\rho$ (Fig. $5 \mathrm{~b}, \mathrm{c}$ ).

Second, to map more precisely the $\lambda$ transcripts whose synthesis was stimulated by $N,{ }^{32} \mathrm{P}$-labeled RNA made in vitro during the transcription of $\lambda$ DNA was hybridized to various DNA fragments derived from the $\lambda p R$ and $p L$ operons (Fig. 6A). We have shown elsewhere that the efficient transcription of DNA fragments lying far downstream from $p R$ and $p L$ depends on $\mathrm{N}$ as well as the host factors NusA, NusB, NusG, and S10 (Mason et al. 1992). The synthesis of $\lambda$ RNA hybridizing to DNA fragments R3-R5 and L2-L4 was inhibited by $\rho$ because these fragments lie downstream of $\rho$-dependent terminators (Fig. 6A). $\rho$-factor also inhibited synthesis of RNA hybridizing to the L1 DNA fragment, although this fragment lies upstream of $t L 1$, probably because lack of translation of the $N$ gene mRNA made in vitro exposes cryptic $\rho$-dependent terminators in this region. Termination of transcription in this region probably depends on the ionic conditions and the presence of NusG in the reaction. $\mathrm{N}$ had no effect on transcription of the $c \mathrm{I}$ gene in the $p R M$ operon or on the synthesis of RNA hybridizing to the R1 fragment upstream of nutR in the $p R$ operon. At $30^{\circ} \mathrm{C} \mathrm{N}$ strongly stimulated the synthesis of RNA hybridizing to downstream DNA fragments regardless of whether $\rho$ was derived from a wild-type strain or from a rho026 mutant strain (data not shown). At $42^{\circ} \mathrm{C}$, however, $\mathrm{N}$ had a strong stimulatory effect on the synthesis of RNA hybridizing to $p R$ operon fragments R3R5 and $p L$ operon fragments L1-L4 only with wild-type $\rho$ (Fig. 6B, cf. line a with b) and not with the mutant Rho026 protein (cf. line c with d). Therefore, the rho026 mutation has a strong and direct effect on the ability of $\mathrm{N}$ to antiterminate transcription at terminators downstream from the $\lambda$ nut sites. The effect of the rho026 mutation on antitermination by $\mathrm{N}$, however, was not absolute. $\mathrm{N}$ still worked weakly in the presence of Rho026 at promoter-proximal sites in the $p L$ operon,
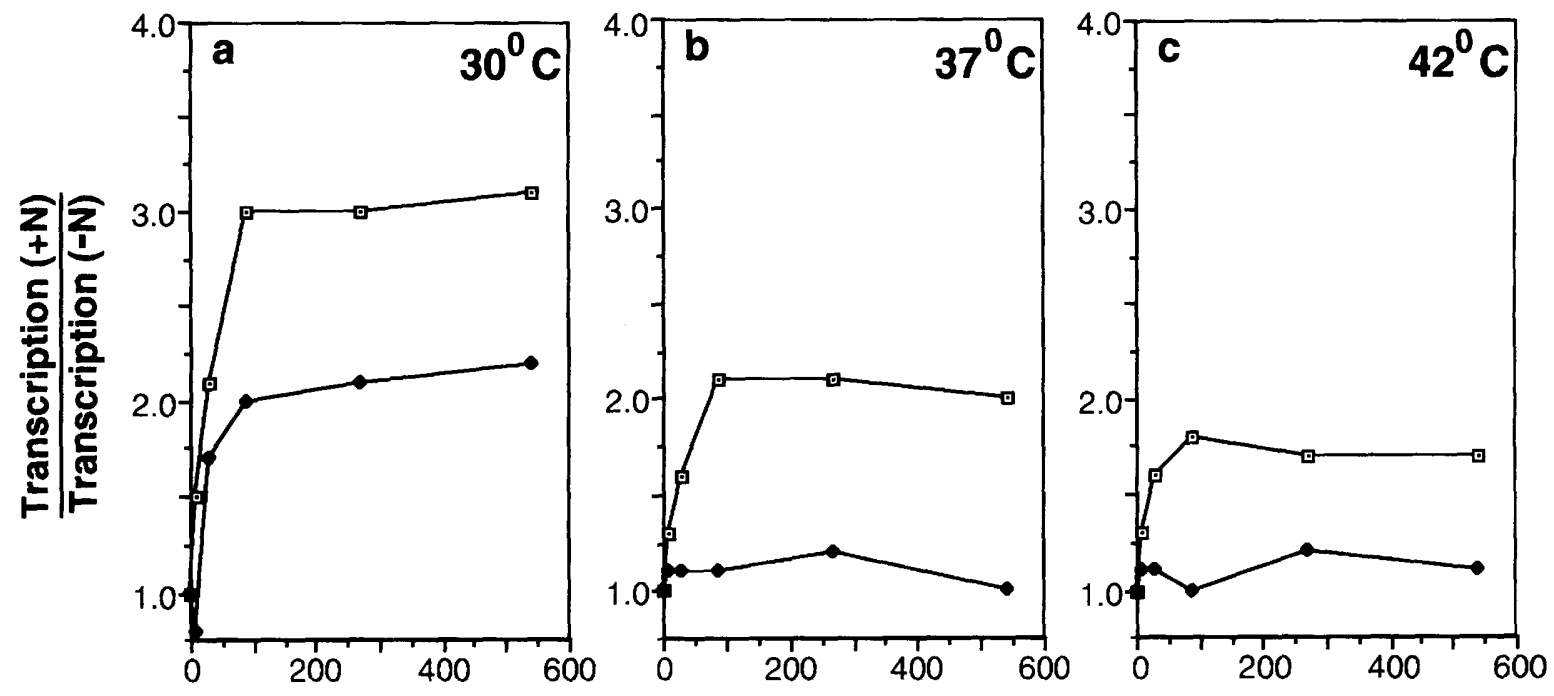

[N] $\mathbf{n M}$

Figure 5. Effect of the rho026 mutation on stimulation of transcription by the $\mathrm{N}$ protein of phage $\lambda$. Transcription reactions were incubated at $30^{\circ} \mathrm{C}(a), 37^{\circ} \mathrm{C}(b)$, or $42^{\circ} \mathrm{C}(\mathrm{c})$ and contained $\lambda$ cI857 S7 DNA, the indicated concentrations of N, NusA (220 nM), NusB $(210 \mathrm{nM})$, NusG $(220 \mathrm{nM})$, ribosomal protein $\mathrm{S} 10$ (185 nM), $10 \mathrm{~mm}$ Tris acetate (pH 7.9), $150 \mathrm{~mm}$ potassium glutamate, $4 \mathrm{~mm} \mathrm{Mg}$ acetate, and $\rho$-factor $(33 \mathrm{nM})$ purified from either a wild-type strain $(\square)$ or a strain with the rho026 mutation ( $)$. Total transcription was measured by assessing the incorporation of $\left[{ }^{3} \mathrm{H}\right] \mathrm{UTP}$ into RNA and related to reactions lacking $\mathrm{N}$. The values (in cpm of incorporated $\left.\left[{ }^{3} \mathrm{H}\right] \mathrm{UTP}\right)$ for the $-\mathrm{N}$ reactions are: $\mathrm{Rho}^{+}\left(30^{\circ} \mathrm{C}\right), 1620$; Rho026 $\left(30^{\circ} \mathrm{C}\right), 1497$; $\mathrm{Rho}^{+}\left(37^{\circ} \mathrm{C}\right), 1548 ; \mathrm{RhoO}^{\circ}\left(37^{\circ} \mathrm{C}\right), 1635 ; \mathrm{Rho}^{+}\left(42^{\circ} \mathrm{C}\right)$, 1353; and Rho026 (42 $\left.{ }^{\circ} \mathrm{C}\right), 1314$. 


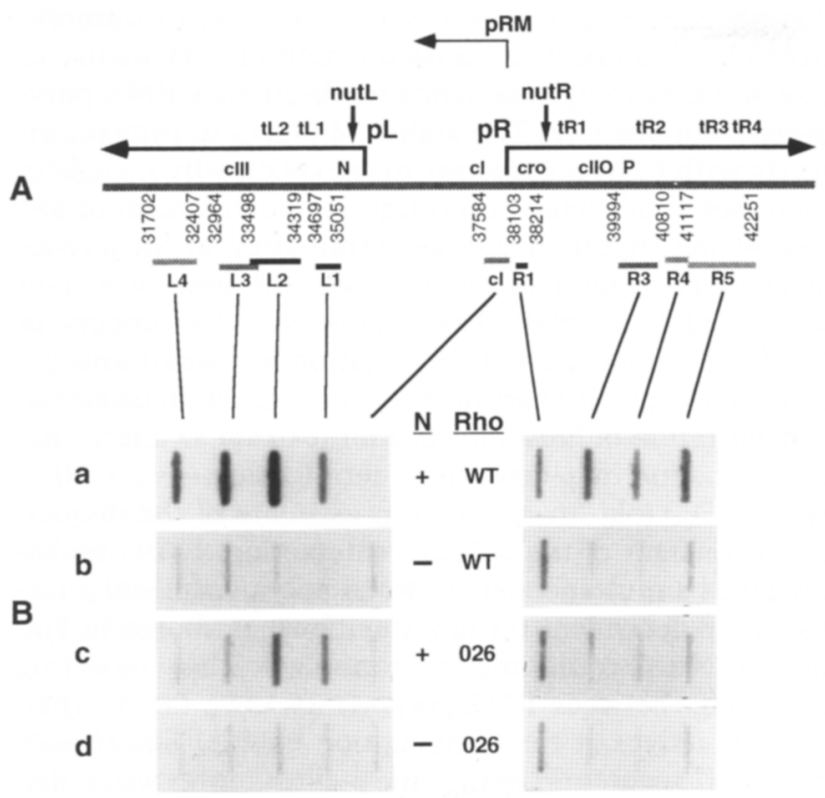

Figure 6. Effect of the rho026 mutation on transcriptional antitermination in the $p R$ and $p L$ operons by the $\mathrm{N}$ protein of phage $\lambda$. (A) Partial genetic and transcriptional map of phage $\lambda$ showing the positions of $\lambda$ DNA fragments used for hybridization. $(B)$ $\lambda c I 857 S 7$ DNA was transcribed at $42^{\circ} \mathrm{C}$ in reactions containing NusA, NusB, NusG, ribosomal protein S10, and $\rho$-factor purified from a wild-type strain or a strain with the rho026 mutation, as indicated. Reactions a and $\mathrm{c}$ also contained $80 \mathrm{~nm} \mathrm{~N}$ protein, as indicated. The reaction buffers and protein concentrations were as indicated in Fig. $5 .{ }^{32} \mathrm{P}$-Labeled RNA made in the reactions was hybridized to the indicated $\lambda$ DNA fragments immobilized on nylon membranes. Autoradiographs of the membranes are shown. There was no detectable hybridization to a control plasmid containing no $\lambda$ DNA insert /data not shown|.

probably because NusG still binds weakly to the Rho026 mutant protein at high temperature (Fig. 7, below).

To determine whether the temperature-sensitive effect of the rho026 mutation on antitermination by $\mathrm{N}$ could be explained by a temperature-sensitive defect in the $\rho-\mathrm{NusG}$ interaction, extracts from $\mathrm{rho}^{+}$and rho026 strains were chromatographed on NusG and control columns at $23^{\circ} \mathrm{C}$ and $39^{\circ} \mathrm{C}$ (Fig. $7 \mathrm{~A}$ ). $\rho$-factor in the $r$ ho ${ }^{+}$and rho026 extracts bound equally well to NusG columns when chromatography was performed at $23^{\circ} \mathrm{C}$ (lanes 2,4$)$. In contrast, $\rho$-factor from the rho026 strain, but not the $\mathrm{rho}^{+}$strain, bound poorly to NusG when chromatography was carried out at $39^{\circ} \mathrm{C}$ (lanes 6,8 ). No other protein in an E. coli extract was important for the effect of the rho026 mutation on the binding of $\rho$ to NusG because highly purified Rho026 mutant protein was similarly defective in binding to NusG columns at $39^{\circ} \mathrm{C}$, but not at $23^{\circ} \mathrm{C}$ (data not shown). At $45^{\circ} \mathrm{C}$ neither wild-type $\rho$ nor the Rho026 protein could bind to a NusG column (Fig. $7 \mathrm{~B}$, lanes 2,4$)$. However, when extract that had been heated at $45^{\circ} \mathrm{C}$ was first cooled to $23^{\circ} \mathrm{C}$ before NusG chromatography, both wild-type and mutant $\rho$ regained the ability to bind NusG (lanes 6,8$)$. This observation, as well as the ability of the Rho026 mutant protein to function well in termination assays at $42^{\circ} \mathrm{C}$ (see Figs. $6 \mathrm{~B}$ and 81 , indicated that the Rho026 protein is not intrinsically thermolabile. Therefore, as the rho026 mutation makes the binding of NusG to $\rho$ temperature sensitive, we conclude that the binding of NusG to $\rho$ is likely important for antitermination by the $\lambda \mathrm{N}$ protein at $\rho$-dependent terminators.

There has been no indication that the rho026 mutation prevents termination by $\rho$-factor at $42^{\circ} \mathrm{C}$ (Simon et al. 1979; Das et al. 1983) even though NusG binds poorly to the Rho026 mutant protein at high temperature (see Fig. 7A). This suggested that the rho026 mutation might cause $\rho$ to have an improved ability to terminate transcription in the absence of NusG. To test this idea, the $\mathrm{Rho}^{+}$and Rho026 proteins were compared at $42^{\circ} \mathrm{C}$ for their ability to inhibit transcription of plasmid pLS1, which contains a $p R-c r o-t R 1$, cassette from $\lambda$, under conditions in which termination by $\rho$ in vitro is stimulated by NusG (Fig. 8). Unlike wild-type $\rho$ factor, the Rho026 mutant protein worked well under these conditions even in the absence of NusG. Therefore, the rho026 mutation simultaneously impairs the interaction of $\rho$-factor with NusG and improves the ability of $\rho$-factor to function in termination in the absence of NusG. This implies that the $\rho-N u s G$ interaction is important both for termination by $\rho$-factor and for antiterimination by $\mathrm{N}$.

\section{Discussion}

We have shown that NusG, a recently identified $E$. coli transcription elongation factor / $\mathrm{Li}$ et al. 1992; Sullivan et al. 1992), interacts directly with termination factor $\rho$. This interaction is highly specific because $\rho$-factor is the

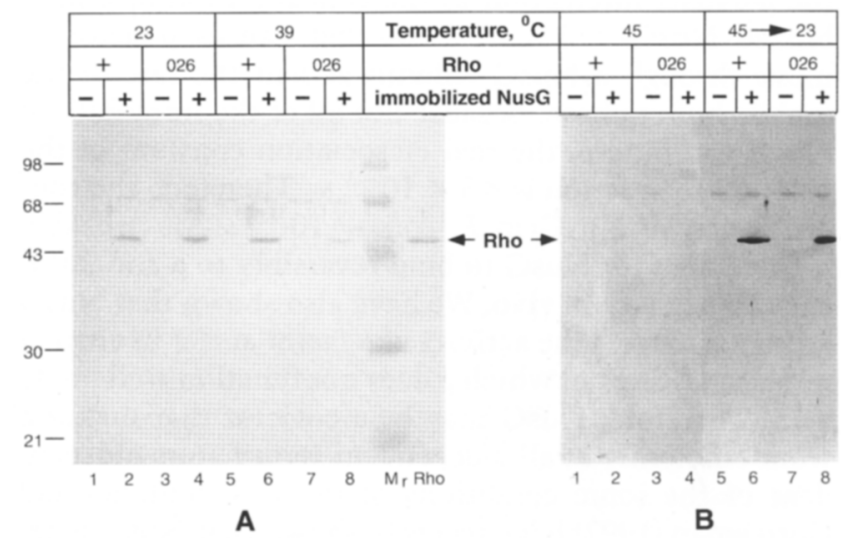

Figure 7. Effect of the rho026 mutation on the binding of $\rho$ to NusG. Extracts from $\mathrm{rho}^{+}$and rho026 strains $(30 \mu \mathrm{l}, 1 \mathrm{mg}$ of protein|, as indicated, were chromatographed on NusG and control columns, as indicated. The $1 \mathrm{M} \mathrm{NaCl}$ eluates from the columns were analyzed by SDS-PAGE followed by Western blotting with anti- $\rho$. $(A)$ Chromatography was performed at $23^{\circ} \mathrm{C}$ or $39^{\circ} \mathrm{C}$, as indicated. Purified $\rho(20 \mathrm{ng})$ was electrophoresed on the same gel as a standard. $(B)$ Extracts were preheated for $20 \mathrm{~min}$ at $45^{\circ} \mathrm{C}$ and chromatographed on NusG and control columns at $45^{\circ} \mathrm{C}$ (lanes $1-4$ ) or cooled to $23^{\circ} \mathrm{C}$ before chromatography on columns at $23^{\circ} \mathrm{C}$ (lanes $5-8$ ). 


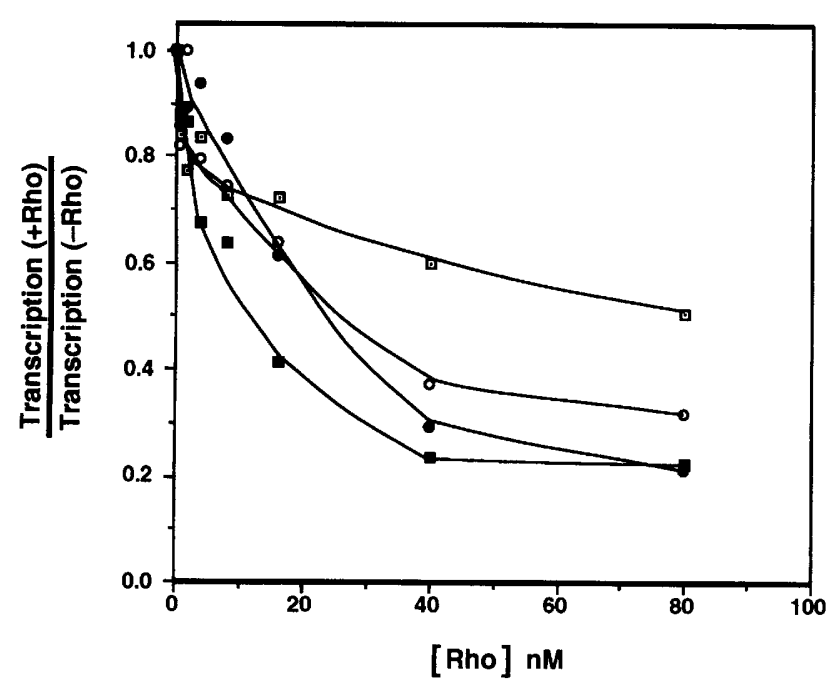

Figure 8. Effect of the rho026 mutation on $\rho$ activity. Reactions containing pLS1 DNA (Lau and Roberts 1985), $10 \mathrm{~mm}$ Tris- $\mathrm{HCl}(\mathrm{pH} 7.9), 200 \mathrm{~mm} \mathrm{KCl}$, and $20 \mathrm{~mm} \mathrm{Mg}$ acetate were incubated at $42^{\circ} \mathrm{C}$ with or without NusG $(500 \mathrm{~nm})$ and with the indicated concentrations of $\rho$-factor, which was purified either from a wild-type strain or from a strain with the rho026 mutation. Total transcription was measured as incorporation of $\left[{ }^{3} \mathrm{H}\right] \mathrm{UTP}$ into RNA and related to reactions lacking $\rho$-factor. (口) $\mathrm{Rho}^{+}$without NusG; (a) Rho ${ }^{+}$with NusG; (O) Rho026 without NusG; (O) Rho026 with NusG.

only E. coli protein that binds reproducibly to immobilized NusG. As judged by quantitative Western blotting with anti-NusG serum, E. coli K-12 cells contain $1 \times 10^{4}$ to $2 \times 10^{4}$ molecules of NusG (data not shown). If we assume that all of the immobilized NusG is able to bind $\rho$-factor, we can calculate the dissociation constant of the $\rho-N u s G$ interaction as the concentration of immobilized NusG $\sim 3 \times 10^{-5} \mathrm{M}$-that causes $\rho$-factor to move through a NusG column at half the rate of the mobile buffer phase. Because not all of the immobilized NusG can bind $\rho$, the real dissociation constant of the $\rho-N u s G$ interaction is $<3 \times 10^{-5} \mathrm{M}$. Therefore, the concentration of NusG in E. coli- $\sim 10^{-5} \mathrm{M}-$-is probably high enough for NusG to bind reversibly to $\rho$ and influence its activity in vivo. We have also shown that NusG greatly improves the activity of $\rho$-factor at $t R 1$ in vitro in ionic conditions in which $\rho$ does not function well on its own. Therefore, NusG may be a cofactor that makes $\rho$ work efficiently at all $\rho$-dependent terminators independent of the ionic conditions of the cell. Sullivan and Gottesman (1992) have recently shown that NusG is required for $\rho$ to terminate transcription in vivo. NusG particularly increased the efficiency of $\rho$-dependent termination at the promoter-proximal termination sites of $t R 1$ (Fig. 3). This may indicate that NusG reduces the length of a nascent $m R N A$ required for a productive interaction of the RNA with $\rho$-factor (Sharp and Platt 1984; Lau and Roberts 1985).

NusG binds directly, but weakly, to immobilized $E$. coli RNA polymerase (Mason and Greenblatt 1991; Li et al. 1992). In spite of this, we have been unable to repro- ducibly detect binding of RNA polymerase to immobilized NusG, probably because the method that we use to attach NusG to agarose tends to obscure its RNA polymerase-binding site. The ability of NusG to interact directly with RNA polymerase may explain why it slightly increases $\rho$-independent termination downstream of $p R^{\prime}$ (Fig. 4) and slightly decreases termination at the $\rho$-independent attenuator preceding the $r p o B$ gene of $E$. coli (Linn and Greenblatt 1991). However, the effects of NusG on $\rho$-independent termination are small and depend on the precise nature of the terminator. Because the concentration of NusG needed for it to act as a termination cofactor in $\rho$-dependent termination- $\sim 5 \times 10^{-8}$ $M$-is $\sim 500$-fold lower than our estimate of the dissociation constant of the $\rho-\mathrm{NusG}$ interaction, NusG probably binds simultaneously to RNA polymerase and $\rho$-factor at a $\rho$-dependent terminator. Thus, as shown in Figure $9 \mathrm{~A}$, NusG could improve termination by $\rho$ by acting as a bridge between RNA polymerase and $\rho$-factor when $\rho$-factor arrives at the transcription bubble. The rho026 mutation apparently makes the $\rho-N u s G$ interaction dispensable for termination by $\rho$-factor. This probably explains why the Rho026 mutant protein can function well in vivo (Simon et al. 1979; Das et al. 1983) even though it cannot bind NusG.

When a transcription unit contains a nut site and $\mathrm{N}$, NusA, NusB, and ribosomal protein S10 are present in the reaction, NusG behaves as a transcriptional antitermination factor ( $\mathrm{Li}$ et al. 1992) for the protein-binding relationships in an $\mathrm{N}$-modified transcription complex, (see Fig. 9B). In this context, NusG and the other factors participate in the cooperative assembly of a stable ribonucleoprotein complex on the surface of RNA polymerase (Horwitz et al. 1987; Mason and Greenblatt 1991; Nodwell and Greenblatt 1991). The nusG4 mutation, which partly reverses the effects of the nus $A 1$ and nusE71 mutations on antitermination by $\mathrm{N}$ (Sullivan et al. 1992), probably makes this ribonucleoprotein complex more stable. As we have shown here, the nusG4 mutation does not affect the binding of $\rho$ to NusG. The effect of the nusG4 mutation suggests that NusG is involved in antitermination by $\mathrm{N}$ in vivo even though Sullivan and Gottesman (1992) have found that NusG is not essential in vivo for antitermination by $\mathrm{N}$, at least at some $\rho$-independent terminators. It is possible that NusG is only necessary for processive antitermination through certain terminators or that some other host factor can partly substitute for NusG to support antitermination by $\mathrm{N}$ in vivo.

The rho026 mutation has a striking effect on antitermination by $\mathrm{N}$ in vivo (Simon et al. 1979; Das et al. 1983) and in vitro (Figs. 5 and 6). Our observation that the rho026 mutation also makes the binding of $\rho$ to NusG temperature sensitive (Fig. 7) implies that the NusG molecule in an $\mathrm{N}$-modified transcription complex is able to interact with $\rho$ (Fig. 9B). In addition, it implies that an interaction between NusG and $\rho$ is important for antitermination by $\mathrm{N}$. The model shown in Figure $9 \mathrm{~B}$ also can explain why weakening of the $\rho-N u s G$ interaction by the rho026 mutation affects antitermination by $\mathrm{N}$ 


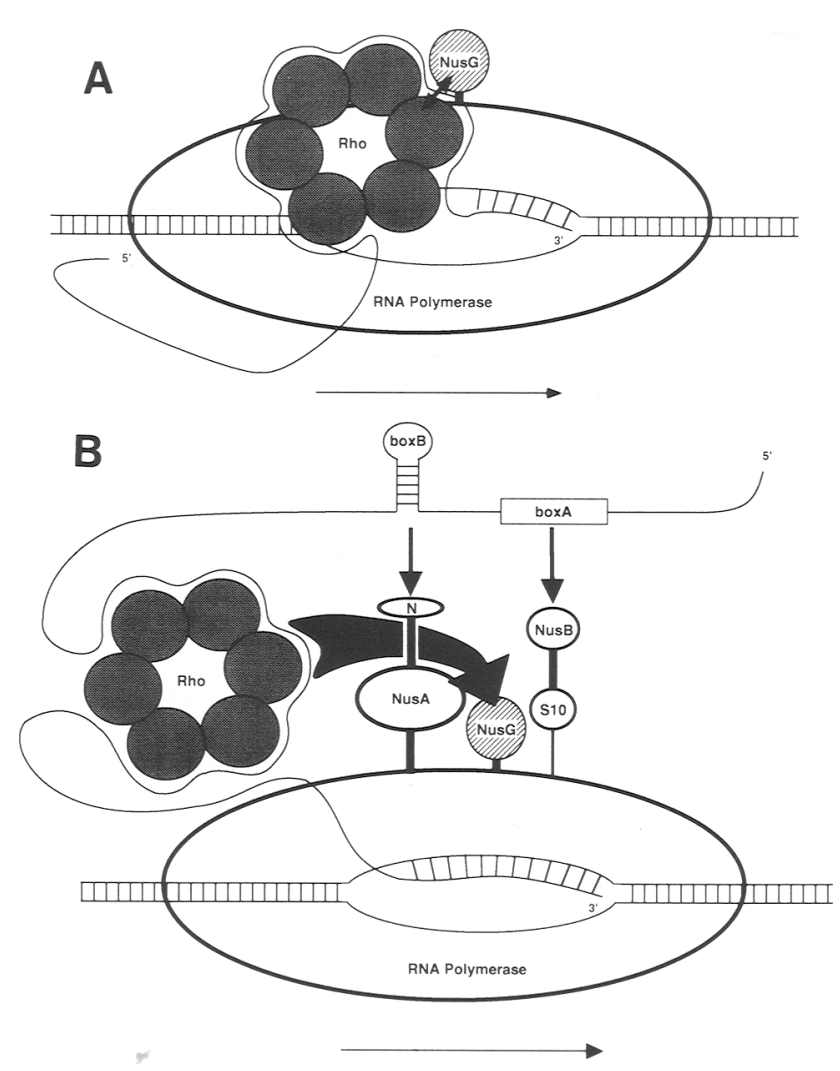

Figure 9. Possible models for the involvement of NusG in termination and antitermination. (A) NusG aids termination by acting as a bridge between RNA polymerase and $\rho$-factor. $(B)$ NusG aids antitermination by sequestering $\rho$-factor. The known protein-protein interactions in an $\mathrm{N}$-modified transcriptional elongation complex are shown. The protein-binding relationships denoted by heavy lines are based on affinity chromatography experiments (Greenblatt and Li 1981a,b; Mason et al. 1991; Li et al. 1992). The binding of S10 to RNA polymerase is based on other experiments (Mason and Greenblatt 1991). The proposed interactions with the box $A$ and $b o x B$ components of nut site RNA are based on RNA protection experiments /Nodwell and Greenblatt 1991). We hypothesize that the NusG molecule whose presence in a $\lambda$ elongation complex depends on $\mathrm{N}$ (Mason and Greenblatt 1991; Li et al. 1992) inhibits termination by sequestering any molecule of $\rho$ that approaches the transcription complex along the nascent mRNA.

more severely at termination sites that are farther downstream from the nut sites (Fig. 6). The observation by Sullivan et al. (1992) that overproduction of NusG suppresses the effect of the rho026 mutation on antitermination by $\mathrm{N}$ is consistent with these conclusions. It is a fascinating curiosity that NusA, NusG, and other E. coli elongation factors involved in transcriptional antitermination by $\mathrm{N}$ can also serve as termination factors in other situations (Greenblatt et al. 1981; Schmidt and Chamberlin 1987; Robledo et al. 1991).

Although we have shown that $\rho$ interacts specifically with NusG, Schmidt and Chamberlin (1984) have shown that purified $\rho$-factor is retarded by a column containing immobilized NusA when the chromatography is per- formed in a low ionic strength buffer. No mutation in NusA or $\rho$-factor that specifically affects the binding of $\rho$ to NusA has been described. Because NusA is one of the most acidic proteins in $E$. coli $(\mathrm{pI}=4.5)$ and $\rho$-factor is very basic (pI $\sim 9$; Yager and Von Hippel 1987), this interaction may not be specific or biologically relevant, particularly as NusA has not been shown to bind $\rho$-factor in preference to the hundreds of other proteins in $E$. coli (Greenblatt and Li 1981b). Therefore, we think that an interaction with NusG, rather than an interaction with NusA, is important for termination by $\rho$-factor.

In an N-modified transcription complex, NusG is stably bound to RNA polymerase (Mason and Greenblatt 1991; Li et al. 1992). Any molecule of $\rho$-factor that is bound to the mRNA in the vicinity of an N-modified transcription complex should bind to the NusG molecule that is present in the transcription complex because its local concentration would be much higher than the local concentration of free NusG (Fig. 9B). The binding of $\rho$ by this tightly bound molecule of NusG may inhibit termination by retarding the ATP-dependent translocation of $\rho$ (Galluppi and Richardson 1980) along the mRNA in the direction of the transcribing RNA polymerase. Only when RNA polymerase had moved farther downstream would the length of the tethering mRNA increase enough for $\rho$ to dissociate from the NusG molecule in the transcription complex. Because the otherwise weak association of NusG with RNA polymerase is stabilized by N (Mason and Greenblatt 1991; Li et al. 1992), this model could partly explain how $\mathrm{N}$ antiterminates transcription at $\rho$-dependent terminators. It is not, however, a sufficient explanation for antitermination by $\mathrm{N}$ because $\mathrm{N}$ can function nonprocessively in the $\mathrm{ab}-$ sence of NusG (Whalen et al. 1988) and because $N$ can function at $\rho$-independent terminators. As with the $Q$ protein of phage $\lambda$ (Grayhack et al. 1985), N probably also suppresses termination by inhibiting pausing by RNA polymerase (Mason et al. 1992).

The box $A$ components of the $\lambda$ nut sites are closely related to the box $A$ sequences of the rrn operons of $E$. coli (Olsen et al. 1982; Morgan 1986; Berg et al. 1989). NusB and NusG are present in transcription complexes synthesizing rRNA in vitro, and the presence of NusB and NusG in these elongation complexes depends on the rrn operon boxA sequence (Li et al. 1992). Furthermore, the nusB5 mutation interferes with chain elongation during the synthesis of rRNA in vivo (Sharrock et al. 1985). Thus, a model similar to that shown in Figure 9B could easily explain why nus $G$ is an essential gene in $E$. coli (Downing et al. 1990) and how box $A$ sequences make RNA polymerase transcribing the rrn operons of $E$. coli resistant to $\rho$-dependent terminators (Holben and Morgan 1984; Li et al. 1984; Gourse et al. 1986; Berg et al. 1989; Albrechtson et al. 1990).

\section{Materials and methods}

\section{Materials}

E. coli RNA polymerase holoenzyme saturated with $\sigma^{70}$ was purified as described by Burgess and Jendrisak (1975). $\rho$-Factor 
was purified from a wild-type E. coli K-12 strain or strain N5032 rho026 (Das et al. 1983) by a modification of the procedure of Sharp et al. (1983), in which their final heparin-agarose chromatography step was replaced with the glycerol gradient centrifugation step of Roberts (1969). NusG and NusG4 were purified as described elsewhere ( $\mathrm{Li}$ et al. 1992), NusG from the $E$. coli K-12 strain N99 (str ${ }^{R}$ galK2) containing the plasmid pU (Downing et al. 1990) and NusG4 from N99 nusA1 nusG4 (pUnusG4). N, NusA, and NusB were purified as described previously (Greenblatt et al. 1980; Greenblatt and Li 1981b; Swindle et al. 1988). Ribosomal protein S10 was generously provided by V. Nowotny (Max Planck Institute, Berlin, Germany), and $\lambda c \mathrm{I}$ repressor, by A. Astromoff and M. Ptashne (Harvard University, Cambridge, MA). $\lambda$ cI857 S7 DNA was isolated from CsCl-purified bacteriophage by phenol-chloroform extraction. pLS1 DNA (Lau and Roberts 1985) was prepared by the alkaline lysis procedure and $\mathrm{CsCl}$ density gradient centrifugation (Maniatis et al. 1982). The Hinfl fragment of pLS1 containing $p R-c r o-t R 1$ was purified by polyacrylamide gel electrophoresis (Maniatis et al. 1982). The construction of derivatives of plasmid pTZ19R (Pharmacia) containing various inserted $\lambda$ DNA fragments has been described elsewhere (Mason et al. 1992). Anti- $\rho$ serum was produced as described previously for anti-NusA and anti-NusB (Horwitz et al. 1987). Western blots were developed with an alkaline phosphatase-coupled second antibody purchased from Bio-Rad.

\section{Affinity chromatography}

Strains SG13060 (rho ${ }^{+}$) and N5032 (rho026) (Simon et al. 1979; Das et al. 1983) grown in $\mathrm{Z}$ medium (Greenblatt and Schleif 1971 ) at $32^{\circ} \mathrm{C}$ to an $A_{550}$ of 3.0 were sonicated at $4^{\circ} \mathrm{C}$ in 1.5 $\mathrm{ml} /$ gram of $10 \mathrm{~mm}$ Tris- $\mathrm{HCl}(\mathrm{pH} 7.4), 10 \mathrm{~mm} \mathrm{Mg}$ acetate, $1 \mathrm{~mm}$ EDTA, $0.5 \mathrm{~mm}$ dithiothreitol, $5 \mu \mathrm{g} / \mathrm{ml}$ of leupeptin, and $12 \mu \mathrm{g} /$ $\mathrm{ml}$ of TPCK. The sonicates were brought to $150 \mathrm{mM} \mathrm{NaCl}$ and centrifuged for $45 \mathrm{~min}$ at $30,000 \mathrm{~g}$. These supernatants and S30 extract from similarly grown JG148 (lac74 ara498 leu498) (Greenblatt and Schleif 1971) were dialyzed at $4^{\circ} \mathrm{C}$ against ACB [10 mM HEPES (pH 7.9), $100 \mathrm{~mm} \mathrm{NaCl}, 0.1 \mathrm{~mm}$ EDTA, $0.1 \mathrm{~mm}$ dithiothreitol, $10 \%$ glycerol and treated with $5 \mu \mathrm{g} / \mathrm{ml}$ of DNase I and $1000 \mathrm{U} / \mathrm{ml}$ of micrococcal nuclease for $2 \mathrm{~min}$ at $37^{\circ} \mathrm{C}$ before use in affinity chromatography. Methods for the immobilization of NusG and for preparing and running microaffinity columns are described elsewhere (Formosa et al. 1991).

\section{Transcription in vitro}

Reactions (usually $20 \mu$ l) were programmed with $11 \mathrm{nM}$ pLS1 DNA, $0.6 \mathrm{nM} \lambda$ cI857 S7 DNA, or $30 \mathrm{~nm}$ of the 560-bp pR-cro$t R 1$-containing HinfI fragment of pLS1. Each reaction contained 40-55 nM RNA polymerase, $0.1 \mathrm{mM}$ dithiothreitol, 150-200 $\mu \mathrm{M}$

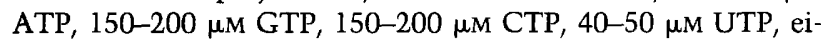
ther $0.2 \mu \mathrm{Ci}\left[{ }^{3} \mathrm{H}\right] \mathrm{UTP}$ or $5-25 \mu \mathrm{Ci}\left[{ }^{32} \mathrm{P} \mid \mathrm{UTP}\right.$, and concentrations of NusG, $\rho$-factor hexamers, N protein, NusA, NusB, ribosomal protein $\mathrm{S10}, \lambda \mathrm{cI}$ repressor, $\mathrm{KCl}, \mathrm{Mg}$ acetate, potassium glutamate, and other salts as indicated in the figures and legends.

Reactions containing $\left[{ }^{3} \mathrm{H}\right]$ UTP were incubated at $37^{\circ} \mathrm{C}$ for 15 min, unless otherwise indicated in figure legends, and total RNA synthesis was measured by spotting aliquots of the reactions on DE81 filters (Goda and Greenblatt 1985).

Runoff transcription assays were preincubated for $10 \mathrm{~min}$ at $37^{\circ} \mathrm{C}$ in the absence of UTP and $\mathrm{Mg}$ acetate. Transcription was initiated by the addition of $\mathrm{Mg}$ acetate, UTP, and $10 \mu \mathrm{g} / \mathrm{ml}$ of rifampicin and continued for $15 \mathrm{~min}$ at $37^{\circ} \mathrm{C}$. Reactions were stopped with $20 \mu \mathrm{l}$ of $40 \mathrm{~mm}$ EDTA, $100 \mathrm{~mm} \mathrm{NaCl}$, and $1 \%$ SDS followed by incubation with $10 \mu \mathrm{g}$ of proteinase $\mathrm{K}$ for $20 \mathrm{~min}$ at $37^{\circ} \mathrm{C}$. Fifteen micrograms of yeast tRNA was added, and nucleic acids were precipitated with isopropanol, washed with $70 \%$ ethanol, dried, boiled in formamide loading buffer, and electrophoresed on a $4 \%$ polyacrylamide gel containing $8 \mathrm{M}$ urea (Maniatis et al. 1982).

Transcription reactions for hybridization experiments $(100$ $\mu l)$ were incubated in the presence of 100 units of RNase inhibitor (Pharmacia) at the indicated temperature for $15 \mathrm{~min}$, followed by treatment with 10 units DNase I (Pharmacia, FPLC pure) at $37^{\circ}$ for $10 \mathrm{~min}$. The reactions were stopped by the addition of $50 \mu \mathrm{l} 50 \mathrm{mM}$ EDTA, $0.5 \%$ SDS, extracted with TEsaturated phenol (BRL) and chloroform/isoamyl alcohol (24:1), and precipitated twice with ethanol. The dried RNA pellets were resuspended in $200 \mu \mathrm{l}$ of $50 \%$ formamide, $3.5 \mathrm{mg} / \mathrm{ml}$ of salmon sperm DNA, and $8 \mathrm{mg} / \mathrm{ml}$ of yeast tRNA. DNA for hybridization (400 pmoles) in $100 \mu$ l of TE was denatured by adding $100 \mu \mathrm{l}$ of $0.8 \mathrm{~N} \mathrm{NaOH}$ at room temperature for $10 \mathrm{~min}$, followed by neutralization with $200 \mu \mathrm{l}$ of $2 \mathrm{M} \mathrm{NH}_{4}$ acetate $(\mathrm{pH}$ 7.0) on ice for $>5 \mathrm{~min}$. This solution was applied to one slot of a Bio-Rad Bio-Dot apparatus containing an ICN Biotrans nylon membrane. Each slot was washed with $500 \mu \mathrm{l}$ of TE, and the DNA was covalently attached by exposing the filter to UV light from a Fotodyne transilluminator. Filters were preincubated for $2-5 \mathrm{hr}$ at $50^{\circ} \mathrm{C}$ in $2.3 \mathrm{ml}$ of hybridization solution $[50 \%$ formamide, $7 \%$ SDS, $50 \mathrm{~mm}$ Na phosphate $[\mathrm{pH} 6.8), 4$ mM EDTA] containing $320 \mu \mathrm{g} / \mathrm{ml}$ of denatured salmon sperm DNA and 150 $\mu \mathrm{g} / \mathrm{ml}$ of yeast tRNA. The labeled RNA was added to the filters in hybridization solution and incubated at $50^{\circ} \mathrm{C}$ for $16 \mathrm{hr}$. The filters were rinsed in $2 \times$ SSC and washed for $15 \mathrm{~min}$ at room temperature successively with $2 \times$ SSC, $0.1 \%$ SDS; $0.5 \times$ SSC, $0.1 \%$ SDS; and $0.1 \times$ SSC, $0.1 \%$ SDS

\section{Acknowledgments}

We thank Max Gottesman and Susan Sullivan for nusG and nusG4 plasmids and strains, Susan Gottesman for strains SG13060 and N5032, Volker Nowotny for providing ribosomal protein S10, Anna Astromoff and Mark Ptashne for providing $\lambda$ $c$ I repressor, and Robert Horwitz for providing anti- $\rho$ serum. This work was supported by the Medical Research Council of Canada. J.G. is an International Research Scholar of the Howard Hughes Medical Institute.

The publication costs of this article were defrayed in part by payment of page charges. This article must therefore be hereby marked "advertisement" in accordance with 18 USC section 1734 solely to indicate this fact.

\section{References}

Albrechtson, B., C.L. Squires, S. Li, and C. Squires. 1990. Antitermination of characterized transcriptional terminators by the Escherichia coli rrnG leader region. I. Mol. Biol. 213: 123-134.

Barik, S., B. Ghosh, W. Whalen, D. Lazinski, and A. Das. 1987. An antitermination protein engages the elongating transcription apparatus at a promoter proximal recognition site. Cell 50: 885-899.

Berg, K.L., C.L. Squires, and C. Squires. 1989. Ribosomal RNA operon antitermination: Function of leader and spacer region box $B$-box $A$ sequences and their conservation in diverse microorganisms. I. Mol. Biol. 209: 345-358.

Brennan, C.A., A.J. Dombroski, and T. Platt. 1987. Transcription termination factor $\rho$ is an RNA-DNA helicase. Cell 48: $945-952$. 
Burgess, R.R. and J.J. Jendrisak. 1975. A procedure for the rapid, large-scale purification of Escherichia coli DNA-dependent RNA polymerase involving polymin $\mathrm{P}$ precipitation and DNA-cellulose chromatography. Biochemistry 14: 4634 4638.

Chen, C.-Y.A., G.R. Galluppi, and J.P. Richardson. 1986. Transcription termination at $t R l$ is mediated by interaction of $p$ with specific single-stranded domains near the $3^{\prime}$ end of cro mRNA. Cell 46: 1023-1028.

Das, A. and K. Wolska. 1984. Transcription antitermination in vitro by lambda $\mathrm{N}$ gene product: Requirement for a phage nut site and the product of host nus $A$, nus $B$ and nusE genes. Cell 38: 165-173.

Das, A., M.E. Gottesman, J. Wardwell, P. Trisler, and S. Gottesman. 1983. A mutation in the Escherichia coli $\rho$ gene that inhibits the $\mathrm{N}$ protein activity of phage. Proc. Natl. Acad. Sci. 80: $5530-5534$.

de Crombrugghe, B., M. Mudryi, R. DiLauro, and M. Gottesman. 1979. Specificity of the bacteriophage lambda $N$ gene product (pN): nut sequences are necessary and sufficient for antitermination by pN. Cell 18: 1145-1151.

Downing, W.L., S.L. Sullivan, M.E. Gottesman, and P.P. Dennis. 1990. Sequence and transcriptional pattern of the essential Escherichia coli secE-nusG operon. J. Bacteriol. 172: 16211627.

Faus, I. and J.P. Richardson. 1990. Structural and functional properties of the lambda cro mRNA that interact with the transcription termination factor Rho. J. Mol. Biol. 212: 5366.

Finger, L.R. and J.P. Richardson. 1982. Stabilization of the hexameric form of Escherichia coli protein $\rho$ under ATP hydrolysis conditions. J. Mol. Biol. 156: 203-219.

Formosa, T., J. Barry, B.M. Alberts, and J. Greenblatt. 1991. Using protein affinity chromatography to probe the structure of protein machines. Methods Enzymol. 208: 24-45.

Friedman, D.I. and L.S. Baron. 1974. Genetic characterization of a bacterial locus involved in the activity of the $\mathrm{N}$ function of phage lambda. Virology 58: 141-148.

Friedman, D.I., G.S. Wilgus, and R.J. Mural. 1973. Gene $N$ regulator function of phage lambda imm21: Evidence that a site of $\mathrm{N}$ action differs from a site of $\mathrm{N}$ recognition. I. Mol. Biol. 81: $505-516$.

Friedman, D.I., M. Baumann, and L.S. Baron. 1976. Cooperative effects of bacterial mutations affecting lambda $N$ gene expression. I. Isolation and characterization of a nusB mutant. Virology 73: 119-127.

Friedman, D.I., A.T. Schauer, M.R. Baumann, L.S. Baron, and S.L. Adhya. 1981. Evidence that ribosomal protein S10 participates in the control of transcription termination. Proc. Natl. Acad. Sci. 78: 1115-1118.

Galluppi, G.R. and J.P. Richardson. 1980. ATP-induced changes in the binding of RNA synthesis termination protein $\rho$ to RNA. I. Mol. Biol. 138: 513-539.

Goda, Y. and J. Greenblatt. 1985. Efficient modification of $E$. coli RNA polymerase in vitro by the $N$ gene transcription antitermination protein of bacteriophage lambda. Nucleic Acids. Res. 13: 2569-2582.

Goldberg, A.R. 1970. Termination of in vitro RNA synthesis by p factor. Cold Spring Harbor Symp. Quant. Biol. 35: 157161.

Gourse, R.L., H.A. de Boer, and M. Nomura. 1986. DNA determinants of rRNA synthesis in E. coli: Growth rate dependent regulation, feedback inhibition, upstream activation, antitermination. Cell 44: 197-205.

Grayhack, E.J., X. Yang, L.F. Lau, and J. Roberts. 1985. Phage lambda gene $Q$ antiterminator recognizes RNA polymerase near the promoter and accelerates it through a pause site. Cell 42: 259-269.

Greenblatt, J. and J. Li. 1981a. The nusA gene product of Escherichia coli; its identification and a demonstration that it interacts with gene $N$ transcription antitermination protein of bacteriophage lambda. I. Mol. Biol. 147: 11-23.

— $1981 \mathrm{~b}$. Interaction of the sigma factor and the nus $A$ gene protein of $E$. coli with RNA polymerase in the initiationtermination cycle of transcription. Cell 24: 421-428.

Greenblatt, J. and R. Scheif. 1971. Arabinose C protein: Regulation of the arabinose operon in vitro. Nature New Biol. 233: $166-170$

Greenblatt, J., P. Malnoe, and J. Li. 1980. Purification of the gene $N$ transcription antitermination protein of bacteriophage $\lambda$. J. Biol. Chem. 255: 1465-1470.

Greenblatt, J., M. McLimont, and S. Hanley. 1981. Termination of transcription by the nusA gene protein of Escherichia coli. Nature 292: 215-220.

Holben, W.E. and E.A. Morgan. 1984. Antitermination of transcription from an Escherichia coli ribosomal RNA promoter. Proc. Natl. Acad. Sci. 81: 6789-6793.

Horwitz, R.J. 1988. "Genetic and structural analysis of bacterial transcription complexes." Ph.D. thesis, University of Toronto, Ontario, Canada.

Horwitz, R.J., J. Li, and J. Greenblatt. 1987. An elongation control particle containing the $N$ gene transcription antitermination protein of bacteriophage lambda. Cell 51: 631-641.

Keppel, F., C. Georgopoulos, and H. Eisen. 1974. Host interference with expression of the lambda $N$ gene product. Biochimie 56: 1503-1509.

Lau, L.F. and J.W. Roberts. 1985. $\rho$-dependent transcription termination at $\lambda \mathrm{tRl}$ requires upstream sequences. I. Biol. Chem. 260: 574-584.

Lau, L.F., J.W. Roberts, and R. Wu. 1983. RNA polymerase pausing and transcript release at the $t R I$ terminator in vitro. $I$. Biol. Chem. 258: 9391-9397.

Li, J., R. Horwitz, S. McCracken, and J. Greenblatt. 1992. NusG, a new Escherichia coli elongation factor involved in transcriptional antitermination by the $\mathrm{N}$ protein of phage lambda. J. Biol. Chem. 267: 6012-6019.

Li, S.C., C.L. Squires, and C. Squires. 1984. Antitermination of E. coli rRNA transcription is caused by a control region segment containing lambda nut-like sequences. Cell 38: 851860.

Linn, T. and J. Greenblatt. 1991. The NusA and NusG proteins of Escherichia coli increase the in vitro readthrough frequency of a transcriptional attenuator preceding the gene for the $\beta$ subunit of RNA polymerase. J. Biol. Chem. 267: 14491454.

Lozeron, H.A., P.J. Anevski, and D. Apirion. 1977. Antitermination and absence of processing of the leftward transcript of coliphage lambda in the RNAse III-deficient host. I. Mol. Biol. 109: 359-365.

Luzzati, D. 1970. Regulation of $\lambda$ exonuclease synthesis: Role of the $N$ gene product and $\lambda$ repressor. I. Mol. Biol. 49: 525-519.

Maniatis, T., E.F. Fritsch, and J. Sambrook. 1982. Molecular cloning: A laboratory manual. Cold Spring Harbor Laboratory, Cold Spring Harbor, New York.

Mason, S.W. and J. Greenblatt. 1991. Assembly of transcription elongation complexes containing the $\mathrm{N}$ protein of phage $\lambda$ and the Escherichia coli elongation factors NusA, NusB, NusG, and S10. Genes \& Dev. 5: 1504-1512.

Mason, S.W., J. Li, and J. Greenblatt. 1991. A direct interaction between two Escherichia coli transcription antitermination factors, NusB and ribosomal protein S10. J. Mol. Biol. 223: $55-66$. 
1992. Host factor requirements for processive antitermination of transcription and suppression of pausing by the $\mathrm{N}$ protein of bacteriophage lambda. I. Biol. Chem. 267: $19418-19426$

Morgan, E.A. 1986. Antitermination mechanisms in rRNA operons of Escherichia coli. J. Bacteriol. 168: 1-5.

Morgan, W.D., D.G. Bear, and P.H. Von Hippel. 1983. p-dependent termination of transcription. 1. Identification and characterization of termination sites for transcription from the bacteriophage $\lambda p R$ promoter. I. Biol. Chem. 258: 95539564.

Morgan, W.D., D.G. Bear, and P.H. Von Hippel. 1984. Specificity of release by Escherichia coli transcription termination factor Rho of nascent mRNA transcripts initiated at the $\lambda p R$ promoter. I. Biol. Chem. 259: 8664-8671.

Morrissey, W.H. 1981. Silver staining for proteins in polyacrylamide gels: A modified procedure with enhanced uniform sensitivity. Anal. Biochem. 117: 307-310.

Nodwell, J.R. and J. Greenblatt. 1991. The nut site of bacteriaphage $\lambda$ is made of RNA and is bound by transcription antitermination factors on the surface of RNA polymerase. Genes \& Dev. 5: 2141-2151.

Oda, T. and M. Takanami. 1972. Observations on the structure of the termination factor $\rho$ and its attachment to DNA. $I$. Mol. Biol. 71: 799-802.

Olsen, E.R., E.L. Flamm, and D.I. Friedman. 1982. Analysis of nutR: A region of phage lambda required for antitermination of transcription. Cell 31: 61-70.

Richardson, J.P. 1970. $\rho$ factor function in T4 RNA transcription. Cold Spring Harbor Symp. Quant. Biol. 35: 127-133.

Richardson, J.P. and R. Conaway. 1980. Ribonucleic acid release activity of transcription termination protein $\rho$ is dependent on the hydrolysis of nucleoside triphosphates. Biochemistry 19: 4293-4299.

Roberts, J.W. 1969. Termination factor for RNA synthesis. Nature 224: 1168-1174.

Robledo, R., B.L. Atkinson, and M.E. Gottesman. 1991. Escherichia coli mutations that block transcription termination by phage HK022 Nun protein. J. Mol. Biol. 220: 613-619.

Rosenberg, M., D. Court, H. Shimatake, C. Brady, and D.L. Wulff. 1978. The relationship between function and DNA sequence in an intercistronic regulatory region in phage lambda. Nature 272: 414-423.

Salstrom, J.S. and W. Szybalski. 1978. Coliphage lambda nut $L^{-}$: A unique class of mutants defective in the site of gene $N$ product utilization for antitermination of leftward transcription. J. Mol. Biol. 124: 195-221.

Schmidt, M.C. and M.J. Chamberlin. 1984. Binding of $\rho$ factor to Escherichia coli RNA polymerase mediated by nusA protein. J. Biol. Chem. 259: 15000-15002.

1987. nusA protein of Escherichia coli is an efficient transcription termination factor for certain termination sites. J. Mol. Biol. 195: 809-818.

Sharp, J.A. and T. Platt. 1984. $\rho$-dependent termination and concomitant NTPase activity requires a specific, intact RNA region. J. Biol. Chem. 259: 2268-2273.

Sharp, J.A., J.L. Galloway, and T. Platt. 1983. A kinetic mechanism for the poly $(\mathrm{C})$-dependent ATPase of the Escherichia coli transcription termination protein, Rho. I. Biol. Chem. 258: 3482-3486.

Sharrock, R.A., R.L. Gourse, and M. Nomura. 1985. Defective antitermination of rRNA transcription and derepression of rRNA and tRNA synthesis in the nusB5 mutant of $E$. coli. Proc. Natl. Acad. Sci. 82: 5275-5279.

Shigesada, K. and C.-W. Wu. 1980. Studies of RNA release reaction catalyzed by $E$. coli transcription termination factor $\rho$ using isolated ternary transcription complexes. Nucleic Acids. Res. 8: 3355-3369.

Simon, L.D., M. Gottesman, K. Tomczak, and S. Gottesman. 1979. Hyperdegradation of proteins in Escherichia coli rho mutants. Proc. Natl. Acad. Sci. 76: 1623-1627.

Sullivan, S.L. and M.E. Gottesman. 1992. Requirement for $E$. coli NusG protein in factor-dependent transcription termination. Cell 68: 989-994.

Sullivan, S.L., D.F. Ward, and M.E. Gottesman. 1992. Effect of Escherichia coli nus $G$ function on $\mathrm{N}$-mediated transcription antitermination. J. Bacteriol. 174: 1339-1344.

Swindle, J., C. Zylicz, C. Georgopoulos, J. Li, and J. Greenblatt. 1988. Purification and properties of the NusB protein of Escherichia coli. I. Biol. Chem. 263: 10229-10235.

Whalen, W., B. Ghosh, and A. Das. 1988. NusA protein is necessary and sufficient in vitro for phage lambda $\mathrm{N}$ gene product to suppress a $\rho$-independent terminator placed downstream of nutL. Proc. Natl. Acad. Sci. 85: 2494-2498.

Yager, T.D. and P. Von Hippel. 1987. Transcript elongation and termination in Escherichia coli. In: Escherichia coli and Salmonella typhimurium. Cellular and molecular biology led. N.C. Neidhardt), vol. 2, pp. 1241-1275. American Society for Microbiology, Washington, D.C.

Zou, L. and J.P. Richardson. 1991. Enhancement of termination factor Rho activity with potassium glutamate. J. Biol. Chem. 266: 10201-10209. 


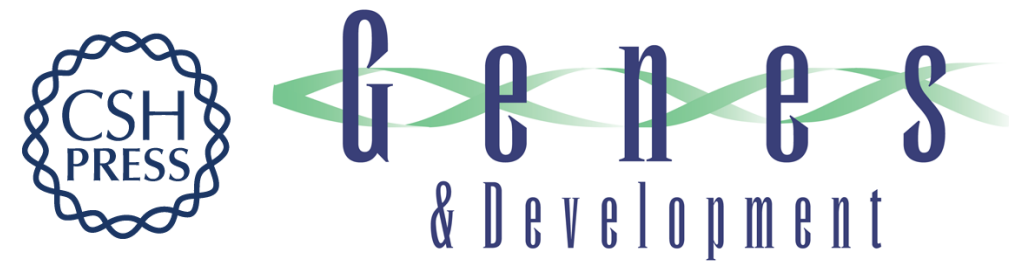

\section{Elongation factor NusG interacts with termination factor rho to regulate termination and antitermination of transcription.}

$\mathrm{J}$ Li, S W Mason and J Greenblatt

Genes Dev. 1993, 7:

Access the most recent version at doi:10.1101/gad.7.1.161

References This article cites 65 articles, 25 of which can be accessed free at: http://genesdev.cshlp.org/content/7/1/161.full.html\#ref-list-1

License

Email Alerting

Service

Receive free email alerts when new articles cite this article - sign up in the box at the top right corner of the article or click here.

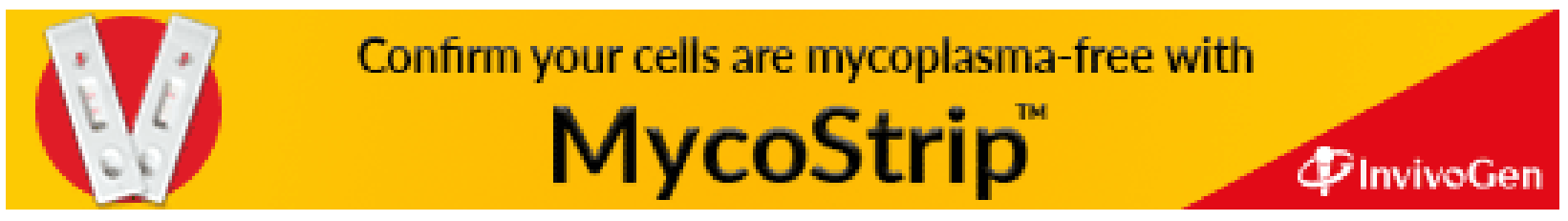

